\title{
Pemalsuan Alat Bukti Atas Penitipan Uang Pajak Oleh Notaris/PPAT dalam Menjalankan Tugas Jabatan
}

\author{
Titin Oktalina Safitri ${ }^{1}$
}

1Program Studi Magister (S2) Kenotariatan Fakultas Hukum Universitas Udayana, BaliIndonesia, E-mail: titinoktalina@yahoo.com

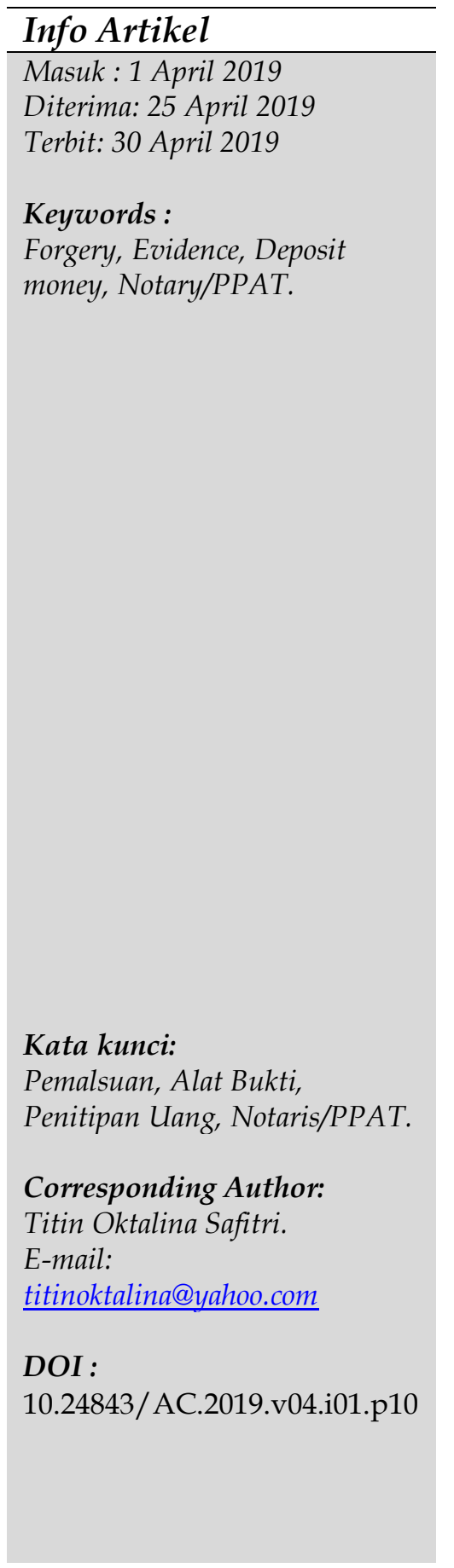

\begin{abstract}
Notary/PPAT is public official who has the authority make authentic deed evidence. Based on trust in Notary/PPAT, all interests in making deed fully entrusted. Included management of BPHTB tax payments authorized to Notary/PPAT. Deposit of tax money by clients based on customary practices aimed at facilitating transaction process. It becomes problem if the original action to help client become act embezzlement money. Based on interviews with Notaries/PPAT in different places stated evidence used sufficient with deposit money. Rules and sanctions have been firmly regulated, but such actions have always taken place in carrying out their duties. Bring up two problems, namely type evidence used in the case of client tax money embezzlement carried out by Notary/PPAT, as well as relation between these actions in carrying out their duties. Purpose of this study is make evidence has legal strength in event of embezzlement, and behavior of the Notary/PPAT to comply with the code of ethics. This study uses empirical legal research based on literature studies and interviews and analyzed using deskripif analysis techniques. The results of the study show important evidence in event of tax evasion cases is proof of receipt which is classified as a proof private deed. However, private deed not yet legal and perfect so the truth can still be denied. Additional legalization is required receipt form of affixing notary stamp and guarantee date and signature receipt. In relation implementation office duties there need for moral and ethics guidance code of ethics so it leads to better behavior.
\end{abstract}

\section{Abstrak}

Notaris/PPAT merupakan pejabat umum yang memiliki kewenangan membuat alat bukti akta otentik. Berdasarkan kepercayaan terhadap Notaris/PPAT, maka segala kepentingan dalam pembuatan akta dipercayakan seluruhnya. Termasuk dalam kepengurusan pembayaran pajak BPHTB yang dikuasakan kepada Notaris/PPAT. Penitipan uang pajak oleh klien didasarkan atas kebiasaan praktik yang bertujuan untuk memudahkan proses transaksi. Menjadi permasalahan apabila tindakan yang semula hanya untuk membantu klien menjadi kasus penggelapan uang. Berdasarkan wawancara dengan Notaris/PPAT di tempat yang berbeda menyatakan bahwa alat bukti yang dipergunakan cukup dengan kwitansi penitipan uang. Aturan dan sanksi telah tegas mengatur, tetapi selalu terjadi tindakan demikian dalam melaksanakan tugas jabatannya. Memunculkan dua permasalahan yaitu jenis alat bukti yang 
digunakan dalam kasus penggelapan uang pajak klien yang dilakukan oleh Notaris/PPAT, serta kaitan tindakan tersebut dalam menjalankan tugas jabatannya. Tujuan penelitian ini agar alat bukti penitipan uang memiliki kekuatan hukum apabila terjadi penggelapan, serta prilaku Notaris/PPAT agar sesuai dengan kode etik. Penelitian ini menggunakan metode penelitian hukum empiris berdasarkan studi kepustakaan dan wawacara serta dianalisis menggunakan teknik analisis deskripif. Hasil penelitian menunjukkan bahwa alat bukti penting apabila terjadi kasus penggelapan uang pajak adalah alat bukti kwitansi yang di golongkan sebagai alat bukti surat dibawah tangan. Pembuktian dengan alat bukti surat dibawah tangan belum sah dan sempurna sehingga masih bisa disangkal kebenarannya. Guna menciptakan kepastian hukum diperlukan adanya tambahan legalisasi berupa pembubuhan cap notaris serta menjamin tanggal dan tanda tangan di dalam kwitansi. Kaitannya dengan pelaksanaan tugas jabatan diperlukan adanya pembinaan moral dan etika di dalam kode etik sehingga menuju kearah prilaku yang lebih baik.

\section{Pendahuluan}

Masyarakat sangat membutuhkan peran notaris dalam melakukan suatu perbuatan hukum. Kewajibannya adalah membuat akta otentik sebagai alat bukti yang sah mengenai perbuatan hukum yang dikehendaki oleh yang berkepentingan berdasarkan peraturan perundang - undangan. ${ }^{1}$ Kepastian hukum adalah hal penting untuk memberikan jaminan perlindungan hukum atas suatu tindakan yang dilakukan. Melakukan perbuatan hukum kaitannya dengan hubungan hak atas tanah maka masyarakat mendatangi notaris selaku Pejabat Pembuat Akta Tanah (selanjutnya disebut PPAT) yang memiliki kewenangan untuk itu. ${ }^{2}$ Peran Notaris/PPAT selaku pejabat umum sangat dipercaya sehingga dalam proses pembuatan akta masyarakat sering menyerahkan segala urusan yang diperlukan. Berkaitan dalam hal memberikan pelayanan jasa hal tersebut merupakan bentuk perbuatan yang memberikan kemudahan kepada kliennya yang datang untuk meminta jasa Notaris/PPAT. ${ }^{3}$ Bertujuan untuk memberikan kepuasan kepada klien dengan pelayanan yang diberikan sehingga klien terus datang kembali.

Sebelum proses pembuatan akta dilakukan maka para pihak selaku wajib pajak diharuskan untuk melakukan pelunasan pajak. Pengenaan pajak adalah bentuk kewajiban sebagai warga Negara yang baik, untuk itu beban pembayaran dilakukan

\footnotetext{
${ }^{1}$ Herlien Budiono. (2014). Dasar Teknik Pembuatan Akta Notaris. Bandung : PT Citra Aditya Bakti. h.1.

2 Urip Santoso. (2016). Pejabat Pembuat Akta Tanah Perspektif Regulasi, Wewenang dan Sifat Akta. Jakarta : Prenadamedia Group. h.39.

3 Arifuddin, Widhiyanti, H. N., \& Susilo, H. (2017). Implikasi Yuridis Terhadap Pejabat Pembuat Akta Tanah Penerima Kuasa Menyetor Uang Pajak Penghasilan/Bea Perolehan Hak Atas Tanah Dan Bangunan Dari Wajib Pajak. Jurnal Ilmiah Pendidikan Pancasila dan Kewarganegaraan Fakultas Hukum Universitas Brawijaya. h, 19.
} 
oleh wajib pajak. ${ }^{4}$ Beberapa situasi tertentu memperbolehkan pembayaran pajak dikuasakan kepada seseorang. Berdasarkan ketentuan Pasal 32 Ayat (3) Undang Undang Nomor 28 Tahun 2007 tentang Ketentuan Umum dan Tata Cara Perpajakan mengatur bahwa pembayaran pajak yang dilakukan oleh wajib pajak dapat dikuasakan kepada seorang kuasa berdasarkan ketentuan peraturan perpajakan. Dalam hal klien yang berkedudukan sebagai wajib pajak dapat mengkuasakan pembayaran pajaknya kepada Notaris/PPAT. Berdasarkan kuasa tersebut maka klien akan menitipkan sejumlah uang pajak dengan tujuan untuk dibayarkan. Penyerahan uang tersebut akan dibuatkan kwitansi pembayaran sebagai alat bukti bahwa telah diserahkannya sejumlah uang. Kwitansi berkedudukan sebagai surat dibawah tangan berdasarkan ketentuan Pasal 1874 BW. Beban pembuktian hanya berupa tanda tangan para pihak sepanjang diakui kebenarannya. Pengaturan mengenai penitipan diatur dalam Pasal 1694 BW apabila seseorang menerima titipan dari orang lain maka dengan harapan untuk disimpan dan dikembalikan sesuai dengan asalnya.

Penitipan uang pajak kepada Notaris/PPAT sering berujung pada penggelapan uang. Kasus penggelapan uang pajak dalam Putusan Pengadilan Tinggi Bandung No.76/PID/2010/PT.Bdg dengan duduk perkara seorang terdakwa yang merupakan Notaris/PPAT bernama Adjie Subandi Dharma Kesuma, SH yang melakukan pemalsuan alat bukti berupa setoran pajak Bea Perolehan Hak Tanah Bangunan (BPHTB). Dalam menjalankan tugas jabatannya terdakwa menyanggupi untuk membantu proses sertifikasi atas tanah PT. Pann Multi Finance berikut segala urusannya mengenai pembayaran pajak. Atas dasar unsur kepercayaan klien kepada Notaris/PPAT dalam melaksanakan tugas jabatannya maka pihak PT diwakili Tatang Suhendar mentransfer sejumlah uang yang nantinya akan digunakan untuk membayar pajak BPHTB. Setelah melakukan pembayaran maka pihak PT meminta bukti pembayaran pajak tersebut kepada terdakwa. Selanjutnya terdakwa melakukan pemalsuan dengan mengisi sendiri bukti setoran BPHTB yang didapat dari petugas lengkap dengan tanda tangan dan cap bank. Setelah bukti tersebut di berikan kepada pihak PT maka dilakukan verifikasi terkait bukti setoran tersebut dan terdapat bukti bahwa telah dipalsukan oleh terdakwa dalam menjalankan jabatannya sehingga terdakwa terindikasi telah melakukan penggelapan uang pajak. Dalam melaksanakan fungsi dan tugasnya seorang Notaris/PPAT haruslah berpedoman pada Undang Undang Jabatan Notaris, Kode Etik Notaris dan Kode Etik PPAT.

Berdasarkan wawancara dengan Ni Nengah Diah Parwitasari, SH.,M.Kn Notaris/PPAT di Kabupaten Tabanan menyatakan bahwa pada praktiknya penitipan uang pajak sering terjadi dengan tujuan memudahkan klien dalam bertransaksi. Tidak ada aturan yang menyatakan bahwa tidak boleh membantu klien dalam urusan pajak terlebih lagi pembayaran pajak dapat dikuasakan. Guna melindungi klien maka dibuatkan kwitansi bahwa telah diserahkannya sejumlah uang kepada Notaris/PPAT. Kwitansi tersebut dirasa cukup untuk melindungi klien manakala terjadinya kasus penggelapan. Apabila terjadi kasus demikian maka Notaris/PPAT telah melanggar ketentuan dalam melaksanakan jabatannya dan wajib untuk dikenakan sanksi. Selanjutnya berdasarkan wawancara dengan Desak Putu Yudiati, SH.,MKn Notaris/PPAT di Kabupaten Badung menyatakan bahwa penitipan uang pajak bertujuan untuk memberikan pelayanan kepada klien dalam proses jual beli. Apabila

${ }^{4}$ H.Bohari. (2012). Pengantar Hukum Pajak. Jakarta : PT Raja Grafindo Persada. h.22. 
dilakukan dengan benar sesuai tujuannya maka tidak akan menjadi masalah. Alat bukti yang digunakan berupa kwitansi yang di dalamnya terdapat redaksi titipan pembayaran pajak yang ditandatangi oleh kedua belah pihak. Kasus penggelapan yang terjadi tentu tidak sesuai dengan pelaksaaan tugas dan jabatan Notaris/PPAT.

Dalam praktiknya tindakan penitipan uang memang sering dilakukan oleh beberapa Notaris/PPAT dengan tujuan hanya untuk memudahkan proses transaksi. Notaris memiliki kewajiban yang tertuang dalam Pasal 16 Undang-Undang Nomor 2 Tahun 2014 tentang Perubahan Atas Undang-Undang Nomor 30 Tahun 2004 tentang Jabatan Notaris (selanjutnya disebut UUJN) yaitu salah satunya adalah bertindak jujur dan menjaga kepentingan para pihak dalam pembuatan akta. Disamping itu kode etik PPAT juga mengatur mengenai tindakan dan kepribadian yang baik untuk dimiliki oleh seorang yang menjalankan tugas sebagai PPAT. Kewajiban sangat berkaitan dengan sanksi apabila ditemukan suatu pelanggaran maka perbuatan tersebut akan dikualifikasikan sebagai suatu tindakan pidana karena melanggar ketentuan peraturan perundang-undangan. ${ }^{5}$ Terdapat beberapa oknum yang menyalahgunakan kewenangan dan jabatannya sehingga membawa tindakan tersebut menjadi kasus penggelapan. Hasil wawancara menyatakan bahwa cukup dengan alat bukti kwitansi penitipan uang akan memberikan jaminan bahwa uang titipan tesebut akan aman. Setelah uang berada di tangan Notaris/PPAT banyak yang menyalahgunakan uang titipan tersebut. Pemalsuan alat bukti yang hanya berupa kwitansi menjadi mudah untuk dilakukan karena berbentuk dibawah tangan. Perlu untuk menguatkan alat bukti kwitansi tersebut guna memberikan jaminan perlindungan hukum terhadap klien yang memiliki itikad baik dalam menggunakan jasa notaris. Dalam penelitian ini penting untuk mengkaji permasalahan yaitu alat bukti yang dapat digunakan dalam kasus penggelapan uang pajak oleh Notaris/PPAT dan akibat pemalsuan alat bukti yang dilakukan notaris/PPAT dalam menjalankan tugas jabatannya.

\section{Metode Penelitian}

Jenis penelitian ini menggunakan metode penelitian hukum empiris. Beranjak dari kebiasaan dalam praktik yaitu penitipan uang pajak yang dilakukan oleh klien kepada Notaris/PPAT. Kasus yang berkembang seiring dengan kebiasaan tersebut adalah kasus penggelapan uang pajak disertai dengan pemalsuan alat bukti. Penting untuk meneliti permasalahan tersebut disertai dengan aturan hukum yang telah mengatur. Tujuannya adalah untuk memberikan kekuatan hukum terhadap alat bukti apabila terjadi penggelapan uang serta tindakan Notaris/PPAT agar sesuai dengan kode etik jabatannya. Data primer diperoleh dari wawancara dengan $\mathrm{Ni}$ Nengah Diah Parwitasari, SH.,M.kn beralamat kantor di Jalan Pulau Menjangan, Dauh Pala, Tabanan. Disertai dengan wawancara dengan Desak Putu Yudiati, SH.,MKn beramat kantor di Jalan Tibung Sari, Kuta Utara, Badung. Data sekunder terdiri dari bahan hukum primer dan bahan hukum sekunder yang berupa bahan - bahan kepustakaan, arsip dan dokumen. Bahan hukum primer berupa Kitab Undang-Undang Hukum Perdata, Undang - Undang Nomor 28 Tahun 2007 tentang Ketentuan Umum dan Tata Cara Perpajakan, Undang-Undang Nomor 2 Tahun 2014 tentang Perubahan Atas Undang-Undang Nomor 30 Tahun 2004 tentang Jabatan Notaris, Kode Etik Notaris

5 Diana, P. V. P., Mertha, I. K., \& Artha, I. G. (2015). Pertanggung Jawaban Notaris Dalam Pembuatan Akta Berdasarkan Pemalsuan Surat Oleh Para Pihak. Acta Comitas, 161-172. h. 162. 
dan Kode Etik PPAT. Bahan hukum sekunder berupa karya ilmiah, penelitian penelitian terdahulu, karya ilmiah praktisi hukum.

\section{Hasil dan Pembahasan}

\subsection{Alat Bukti Tertulis Penitipan Uang Pajak Kepada Notaris / PPAT}

Perbuatan hukum yang dilakukan oleh masyarakat menuntut adanya pembuktian untuk menentukan benar atau tidak tindakan tersebut dilakukan. Pengertian pembuktian secara yuridis adalah kepastian mengenai fakta - fakta yang menunjukan adanya suatu peristiwa dalam hubungan hukum. ${ }^{6}$ Sekalipun perbuatan tersebut dilakukan dihadapan pejabat yang berwenang alat bukti tetap sangat diperlukan. Alat bukti menurut Pasal 1866 BW dibedakan menjadi surat atau bukti tertulis, saksi, persangkaan, pengakuan dan sumpah. Alat bukti surat merupakan bukti tulisan yang dapat dilihat dan dibaca serta dibuktikan kebenarannya terhadap si pembuat. Menjadi penting apabila terjadinya suatu permasalahan terhadap suatu hal. Bukti tulisan akan memuat fakta bahwa telah terjadi perbuatan hukum diantara para pihak. Menurut pandangan hakim alat bukti tertulis dapat dijadikan acuan dalam memutus perkara terlebih untuk perkara yang memiliki kompleksitas yang tinggi. Apabila dilihat dari sudut pandang para pihak mereka akan merasa aman dan terlindungi apabila memiliki alat bukti yang dapat menguatkan dan melemahkan pihak lawan. Alat bukti tertulis dibedakan menjadi akta otentik dan akta dibawah tangan.

\section{a. Akta Otentik}

Akta yang dibuat oleh pejabat yang berwenang dengan bentuk yang ditentukan oleh undang-undang merupakan akta otentik yang memiliki pembuktian yang sah dan sempurna. Perjanjian yang dituangkan dan dibuat secara otentik memiliki tingkat kepastian hukum yang tinggi. Didalamnya harus mengandung unsur subyektif dan obyektif dari kehendak para pihak yang dituangkan ke dalam akta. ${ }^{7}$ Unsur subyektif berhubungan dengan pihak di dalam akta yang berarti bahwa dalam membuat akta para pihak telah sepakat mengenai hal yang diperjanjikan. Para pihak juga harus cakap hukum yaitu sudah berumur 17 (tujuh belas tahun) dan tidak sedang dalam pengampuan. Unsur obyektif berkaitan dengan hal yang diperjanjikan sehingga hal tersebut dapat menjadi dasar dibuatnya akta dengan tidak bertentangan dengan undang - undang. Akta otentik juga memuat mengenai kepastian tanggal dan tanda tangan. Bahwa pada hari dan tanggal serta waktu yang disebutkan dalam akta benar telah hadir dan menghadap para pihak dihadapan notaris untuk melakukan perbuatan hukum. Penutup akta segera ditanda tangani oleh para pihak, saksi dan notaris setelah akta dibacakan seluruhnya. Fungsi pembacaan akta adalah untuk memastikan bahwa para pihak mengetahui dan mengerti betul seluruh isi akta yang telah dibahasakan dan dibuat oleh notaris. Bahasa akta menggunakan bahasa Indonesia namun apabila diperlukan atau salah satu pihak adalah WNA maka akta dapat diterjemahkan ke dalam bahasa asing. Akta yang digunakan untuk pembuktian tetaplah akta yang menggunakan bahasa Indonesia. Pembuatan akta otentik sangat penting karena akan dijadikan alat bukti formil dikemudian hari mana kala terjadinya sengketa. Pejabat

\footnotetext{
${ }^{6}$ Krisna Harahap. (2008). Hukum Acara Perdata. Bandung: PT. Grafitri Budi Utami. h. 67.

7 Diatmika, I. G. A. O., Atmadja, I. D. G., \& Sri Utari, N. K. (2017). Perlindungan Hukum Terhadap Jabatan Notaris Berkaitan Dengan Adanya Dugaan Malpraktek Dalam Proses Pembuatan Akta Otentik. Acta Comitas. h.156.
} 
yang berwenang dalam hal ini Notaris/PPAT dalam membuat akta otentik harus memperhatikan kewenangan dan kewajibannya serta segala larangan dari peraturan peraturan yang berkaitan dengan pembuatan akta otentik agar pembuktian akta menjadi sempurna.

\section{b. Akta Dibawah Tangan}

Surat yang dibuat sendiri oleh para pihak tanpa pejabat yang berwenang disebut dengan akta di bawah tangan. Bentuk serta isi nya bebas menguraikan mengenai kehendak para pihak serta ditandatangi. Beban pembuktian diletakkan pada pengakuan dari pembuat akta tersebut. Bahwa memang benar telah terjadi kesepakatan serta tanda tangan yang dibubuhkan pada surat tersebut adalah asli. Akta dibawah tangan memiliki pembuktian bebas terhadap kepentingan siapa saja. ${ }^{8}$ Tanda tangan memiliki makna sebagai suatu keabsahan dari perbuatan. ${ }^{9}$ Perjanjian yang termuat dalam akta dibawah tangan adalah sah apabila telah diakui kebenarannya walaupun bentuknya tidak diatur. Unsur - unsur perjanjian yang terdapat pada syarat sah nya perjanjian terpenuhi maka perjanjian dibenarkan. Syarat pertama adalah adanya kesepakatan yang timbul diantara para pihak dan menuangkannya ke dalam akta. Berikutnya adanya kecakapan dalam melakukan perbuatan hukum dari para pihak. Adanya suatu hal yang menjadi objek perjanjian serta objek tersebut adalah hal yang tidak melanggar kesusilaan serta undang - undang.

Kaitan alat bukti surat dalam kasus penggelapan uang pajak dalam prakteknya apabila terjadi penitipan uang maka Notaris/PPAT akan membuatkan kwitansi dengan redaksi titipan uang pajak. Berdasarkan hasil wawancara dengan Notaris/PPAT di dua tempat berbeda alat bukti berupa kwitansi dirasa sudah cukup untuk memberi perlindungan hukum kepada kliennya. Kedudukan kwitansi adalah sebagai surat dibawah tangan yang tidak memiliki beban pembuktian yang sah dan sempurnya. Terjadinya kasus penggelapan dan alat bukti kwitansi di bantah oleh salah satu pihak maka pembuktian harus dibuktikan lagi oleh hakim dengan pertimbangan hukum. Melihat pada substansinya akta dibawah tangan memiliki daya pembuktian keluar yaitu pembuktian keaslian tanda tangan yang dibantah oleh pihak lain harus dibuktikan kebenarannya oleh pihak lawan. ${ }^{10}$ Tentu keadaan demikian melemahkan pihak klien selaku pemilik uang dengan alat bukti surat yang tidak otentik. Ditambah lagi pada kasus diatas tindakan Notaris/PPAT adalah melakukan pemalsuan bukti setoran BPHTB dengan tidak membayarkan pajak tersebut dan menggunakan uang klien untuk kepentingan pribadi. Kewenangan jabatan yang dimiliki dapat dengan mudah untuk bekerja sama dengan oknum yang tidak bertanggung jawab dan membuat bukti palsu. Tindakan tersebut berani dilakukan karena lemahnya alat bukti yang dapat melemahkan kedudukan Notaris/PPAT. Guna melindungi pihak klien maka dalam pembuatan kwitansi penitipan uang pajak, disamping ditandatangi oleh para pihak juga harus di legalisasi. Pasal 15 UUJN menyatakan salah satu kewenangan notaris adalah mengesahkan tanda tangan para pihak dalam surat dibawah tangan

\footnotetext{
8 Tjukup, I. K., Layang, I. W. B. S, Martana, N. A., Asmara Putra, D. N. R. A., Arsha Putra, I. P. R., Sari Dewi, I. G. A. T., \& Jayanthi, N. M. D. (2016). Kekuatan Hukum Pembuktian Waarrmerken (Akta Dibawah Tangan Yang Didaftarkan) Di Notaris. Acta Comitas. h. 160.

9 H. Salim HS. (2017). Teknik Pembuatan Akta Perjanjian (TPA Dua). Jakarta : PT RajaGrafindo Persada, h. 41.

10 Krisna Harahap. Op.Cit h. 77.
} 
serta menetapkan kepastian tanggal dan didaftarkan dalam buku legalisasi. Pembubuhan cap notaris pada akta dibawah tangan adalah bentuk pengesahan dalam legalisasi. ${ }^{11}$ Melaksanakan tugas jabatan melindungi kepentingan para pihak mencegah terjadinya sengketa termasuk juga tindakan curang dari pejabat yang berwenang yaitu Notaris/PPAT.

\subsection{Akibat Pemalsuan Alat Bukti Yang Dilakukan Notaris/PPAT Kaitannya Dalam Menjalankan Tugas Jabatan}

Jabatan selaku Notaris/PPAT adalah suatu jabatan yang diberikan kewenangan oleh undang-undang untuk membuat akta otentik. Notaris diangkat oleh Menteri Hukum dan Hak Asasi Manusia sedangkan PPAT diangkat oleh Kepala Badan Pertanahan Nasional. Kewenangan yang dimiliki keduanya adalah untuk membuat alat bukti surat yang otentik. PPAT mengkhusus pada perjanjian yang berhubungan dengan hak atas tanah. Disamping ketentuan peraturan perundang-undangan, setiap profesi memiliki kode etik yang wajib untuk di taati. Kode etik adalah kaidah moral dan norma yang dibentuk secara internal anggota yang wajib untuk dipatuhi dan merupakan pedoman dalam melaksanakan profesinya. ${ }^{12}$ Kode Etik Notaris dibentuk oleh Ikatan Notaris Indonesia (INI) yang didalamnya memuat kewajiban, kewenangan, larangan serta sanksi bagi pelanggarnya.

Berkaitan dengan moralitas dalam Pasal 3 Kode Etik menjabarkan kewajiban notaris yaitu :

1. Memiliki pribadi, moral serta akhlak yang baik. Selaku Notaris sebelum menjalankan jabatannya dan pada saat melakukan sumpah jabatan wajib secara bersungguh-sungguh untuk mendedikasikan dirinya selaku pejabat umum. Nilai moral harus dijunjung tinggi untuk memilih perbuatan yang baik dan buruk sehingga melaksanakan tugasnya sesuai dengan aturan.

2. Bersikap saling menghormati serta menjunjung tinggi Jabatan Notaris. Notaris memiliki wadah perkumpulan yaitu INI yang anggotanya diikuti oleh Notaris seluruh Indonesia. Antara sesama rekan harus memiliki toleransi dengan tidak saling menjatuhan antara satu dengan lainnya. Menjungjung tinggi jabatan sangat diperlukan karena sekali perbuatan buruk yang dilakukan oleh oknum akan berdampak pada rekan dan lembaga.

3. Memiliki prilaku jujur, mandiri serta tidak berpihak. Kejujuran adalah modal utama yang wajib untuk dimiliki oleh Notaris. Sebab menjalankan profesi ini tidaklah mudah apabila tidak didasari pada kejujuran maka akan menggiring pada perbuatan yang melanggar hukum. Keberpihakan juga dilarang karena posisi notaris adalah sebagai pihak yang netral antara para pihak guna mencegah terjadinya sengketa kemudian.

Dalam rangka perlindungan terhadap masyarakat maka penegakan mengenai pematuhan kode etik perlu untuk dilakukan. Pelanggaran yang dilakukan oleh notaris juga akan berakibat pada produk hukumnya yaitu akta yang kehilangan daya

11 Dinaryanti, A. R. (2013). Tinjauan Yuridis Legalisasi Akta Dibawah Tangan Oleh Notaris. Jurnal Ilmu Hukum Legal Opinion. h. 6.

12 Ma'arif, A. (2011). Implementasi Kode Etik Notaris Dalam Aktivitas Notaris Sebagai Pejabat Umum. (Tesis Universitas Diponogoro). h. 21. 
otentiknya. ${ }^{13}$ Pelaksanaan jabatan PPAT juga dituangkan dalam bentuk kode etik PPAT. Pada dasarnya pengaturan kode etik keduanya adalah sama-sama mengedepankan moralitas selaku pejabat umum. Aspek kejujuran memiliki urutan tertinggi dalam menentukan kinerja Notaris/PPAT. Apabila jujur dan beretika masyarakat pun dapat memilih kemana akan membuat akta. Disamping sebagai pejabat yang berwenang Notaris/PPAT juga penyedia jasa yang perlu untuk mengadakan hubungan yang baik dengan kliennya. Dalam praktiknya salah satu bentuk pelayanan jasa yang dilakukan adalah dalam hal menerima titipan pajak. Dilihat dari sisi aturannya menerima titipan pajak tidak dilarang hal ini timbul dari kebiasaan praktik yang biasa dilakukan dan tidak akan menimbulkan masalah manakala Notaris/PPAT penerima titipan berprilaku jujur. Berbeda hal nya apabila kepercayaan klien dicederai dengan tindakan penggelapan. Tindakan kecurangan dan ketidak jujuran timbul dari permasalaan moralitas dan etika yang marak terjadi. Pengaturan moral sangat bergantung pada pribadi yang bersangkutan sehingga penegakannya sangat sulit untuk dilakukan apabila tidak di awali dengan kesadaran diri sendiri. ${ }^{14}$ Landasan filosofis dari kode etik adalah bahwa Notaris/PPAT merupakan orang yang ahli di bidang ilmu kenotariatan sehingga diharapkan mampu untuk memenuhi kebutuhan masyarakan serta memiliki tanggung jawab untuk peningkatan mutu pelayanan. ${ }^{15}$

Tindak penggelapan yang dilakukan oleh Notaris/PPAT apabila dilihat dari aspek pertanggung jawaban baik secara perdata atau pun pidana sudah diatur secara tegas. Dalam hal hubungan hukum dengan kliennya maka dapat dimintakkan pertanggung jabawan secara perdata. Sesuai pasal 84 UUJN pihak yang merasa dirugikan dapat menuntut ganti kerugian kepada Notaris. Pertanggung jawaban dari unsur pidana terdapat pada Pasal 372 KUHP yang dengan sengaja melakukan tindak penggelapan dengan ancaman pidana 4 (empat) tahun. Aturan dan sanksi nya sudah jelas terdapat dalam ketentuan peraturan - undangan. Tindak penggelapan seperti ini tetap masih sering terjadi. Langkah yang harus dilakukan baik oleh pribadi Notaris/PPAT dan juga bersama-sama dengan lembaga INI adalah pembenahan dan penerapan nilai moralitas yang terdapat pada kode etik. Tindakan penggelapan dengan modus pemalsuan surat dapat dilakukan oleh Notaris/PPAT karena tidak memiliki moral dan prilaku yang jujur. Keadaan apapun dapat memanipulasi harkat dan martabat jabatanya selaku pejabat umum. Cakupan kode etik lebih luas bila dibandingkan dengan sanksi semata. Diperlukan peran serta Majelis Kehormatan Notaris selaku badan di dalam keanggotan INI yang memiliki kewenangan untuk mengadakan pengawasan serta pembinaan Notaris. ${ }^{16}$ Pengawasan dan sanksi diperlukan untuk menimbulkan efek jera, namun pembinaan lebih penting untuk dilakukan. Pengertian dari pembinaan adalah tindakan atau langkah pembaharuan. Dalam proses

13 Purwaningsih, E. (2011). Penegakan Hukum Notaris Dalam Pembuatan Perjanjian Berdasarkan Pancasila Dalam Rangka Kepastian Hukum. Jurnal Hukum Fakultas Hukum Yarsi. h. 329.

14 Saputra, D., Wahyuninggsih, S. E. (2017). Prinsip Kehati - Hatian Bagi Notaris/PPAT Dalam Menjalankan Tupoksinya Dalam Upaya Pencegahan Kriminalisasi Berdasarkan Kode Etik. Jurnal Program Magister Kenonatriatan Fakultas Hukum UNISSULA, h. 349.

15 Supriyanta. (2013). Kajian Filosofis Terhadap Standar Perilaku Etis Notaris. Jurnal Fakultas Hukum Universitas Slamet Riyadi Surakarta. h.139.

16 Maya, E. A. (2017). Kedudukan Dan Kewenangan Majelis Kehormatan Notaris Dalam Pembinaan Terhadap Notaris. Jurnal Magister Kenotariatan Universitas Mataram. h.248. 
pembinaan sangat diperlukan adanya langkah-langkah pencegahan serta solusi dalam pemecahan masalah. Moral dan etika Notaris/PPAT dalam menjalankan tugas jabatan berubah kearah yang lebih baik. Pertaruhan kinerja dan kepercayaan masyarakat terhadap lembaga notaris dalam menjalankan tugasnya harus dijaga. Demi keberlangsungan dan keseimbangan birokrasi antara pemerintah dan warga Negara yang dijembatani oleh Notaris/PPAT dalam pembuatan suatu dokumen yang otentik.

\section{Kesimpulan}

Alat bukti yang dapat dijadikan bukti yang kuat manakala terjadi kasus penggelapan uang pajak adalah alat bukti surat. Kwitansi merupakan alat bukti surat dibawah tangan yang masih bisa disangkal oleh pihak lain sehingga masih belum dikatakan sebagai alat bukti yang sah dan sempurna. Dalam praktik penitipan uang pajak kedudukan antara Notaris/PPAT dan klien tidak seimbang. Dikarenakan alat buktinya hanya berupa kwitansi penitipan uang. Terlebih lagi dengan segala keilmuan di bidang hukum kenotariatan yang dimiliki Notaris/PPAT akan memudahkan apabila ingin melakukan pemalsuan alat bukti. Perlu untuk memberikan ketegasan dari bukti surat dibawah tangan dengan melakukan legalisasi. Kewenangan Notaris dalam Pasal 15 UUJN termasuk juga didalamnya kewenangan mengenai legalisasi surat. Pemubuhan cap dan memastikan kebenaran tanggal surat tersebut, sehingga akan memperkuat alat bukti dihadapan hakim dalam memutus perkara yang serupa.

Akibat pemalsuan surat pada saat melakukan penggelapan uang pajak yang dilakukan oleh Notaris/PPAT kaitannya dalam melaksanakan tugas jabatan banyak terjadi. Ketentuan sanksi baik secara perdata atau pun pidana sudah tegas diatur dan mengikat apabila dilanggar. Faktor penyebab selalu timbulnya hal demikian adalah lemahnya etika dan moral yang seharusnya dimiliki oleh seorang pejabat umum. Aturan yang terdapat pada kode etik wajib untuk dipatuhi. Ditambah dengan adanya pembinaan guna merubah tingkah laku Noaris/PPAT kearah yang lebih baik. Berikut di dalamnya kesadaran dari diri sendiri serta faktor pendukung yaitu Majelis Kehormatan Notaris dalam melaksanakan pembinaan Notaris/PPAT di Indonesia.

\section{Daftar Pustaka}

\section{Buku}

Budiono, Herlien. (2014). Dasar Teknik Pembuatan Akta Notaris. Bandung : PT Citra Aditya Bakti.

Harahap, Krisna. (2008). Hukum Acara Perdata. Bandung : PT. Grafitri Budi Utami.

H. Bohari. (2012). Pengantar Hukum Pajak. Jakarta : PT Raja Grafindo Persada.

HS, H. Salim. (2017). Teknik Pembuatan Akta Perjanjian (TPA Dua). Jakarta : PT Raja Grafindo Persada.

Santoso, Urip. (2016). Pejabat Pembuat Akta Tanah Perspektif Regulasi, Wewenang dan Sifat Akta. Jakarta : Prenadamedia Group.

\section{Jurnal}

Arifuddin, Widhiyanti, H. N., \& Susilo, H. (2017). Implikasi Yuridis Terhadap Pejabat Pembuat Akta Tanah Penerima Kuasa Menyetor Uang Pajak Penghasilan/Bea Perolehan Hak Atas Tanah Dan Bangunan Dari Wajib Pajak. Jurnal Ilmiah Pendidikan Pancasila dan Kewarganegaraan Fakultas Hukum Universitas Brawijaya. h, 19. 
Diana, P. V. P., Mertha, I. K., \& Artha, I. G. (2015). Pertanggung Jawaban Notaris Dalam Pembuatan Akta Berdasarkan Pemalsuan Surat Oleh Para Pihak. Acta Comitas, 161-172. h. 162.

Diatmika, I. G. A. O., Atmadja, I. D. G., \& Sri Utari, N. K. (2017). Perlindungan Hukum Terhadap Jabatan Notaris Berkaitan Dengan Adanya Dugaan Malpraktek Dalam Proses Pembuatan Akta Otentik. Acta Comitas. h.156.

Dinaryanti, A. R. (2013). Tinjauan Yuridis Legalisasi Akta Dibawah Tangan Oleh Notaris. Jurnal Ilmu Hukum Legal Opinion. h. 6.

Maya, E. A. (2017). Kedudukan Dan Kewenangan Majelis Kehormatan Notaris Dalam Pembinaan Terhadap Notaris. Jurnal Magister Kenotariatan Universitas Mataram. h.248.

Purwaningsih, E. (2011). Penegakan Hukum Jabatan Notaris Dalam Pembuatan Perjanjian Berdasarkan Pancasila Dalam Rangka Kepastian Hukum. Jurnal Hukum Fakultas Hukum Yarsi. h. 329.

Saputra, D., Wahyuninggsih, S. E. (2017). Prinsip Kehati - Hatian Bagi Notaris/PPAT

Dalam Menjalankan Tupoksinya Dalam Upaya Pencegahan Kriminalisasi Berdasarkan Kode Etik. Jurnal Program Magister Kenonatriatan Fakultas Hukum UNISSULA, h. 349.

Supriyanta. (2013). Kajian Filosofis Standar Perilaku Etis Notaris. Jurnal Fakultas Hukum Universitas Slamet Riyadi Surakarta. h.139.

Tjukup, I. K., Layang, I. W. B. S, Martana, N. A., Asmara Putra, D. N. R. A., Arsha Putra, I. P. R., Sari Dewi, I. G. A. T., \& Jayanthi, N. M. D. (2016). Kekuatan Hukum Pembuktian Waarrmerken (Akta Dibawah Tangan Yang Didaftarkan) Di Notaris. Acta Comitas. h. 16.

\section{Tesis/Disertasi}

Ma'arif, A. (2011). Implementasi Kode Etik Notaris Dalam Aktivitas Notaris Sebagai Pejabat Umum. Tesis Universitas Diponogoro. h.21.

\section{Peraturan Perundang - Undangan}

Kitab Undang-Undang Hukum Perdata (Burgerlijk Wetboek).

Undang-Undang Republik Indonesia Nomor 28 Tahun 2007 tentang Ketentuan Umum dan Tata Cara Perpajakan. Lembaran Negara Republik Indonesia Tahun 2007 Nomor 85, Tambahan Lembaran Negara Republik Indonesia Nomor 4740.

Undang-Undang Republik Indonesia Nomor 2 Tahun 2014 tentang Perubahan Atas Undang-Undang Nomor 30 Tahun 2004 Tentang Jabatan Notaris, Lembaran Negara Republik Indonesia Tahun 2014 Nomor 293, Tambahan Lembaran Negara Republik Indonesia Nomor 5602.

Kode Etik Notaris.

Kode Etik Pejabat Pembuat Akta Tanah. 